\title{
Architecture, Festival and the City: Introduction
}

Formatted: Font colour: Text 1

María José Martínez Sánchez, Christian Frost, Jieling Xiao

\section{Authors' contact details:}

María José Martínez Sánchez

School of Architecture and Design, Birmingham City University, UK

maria.martinez@bcu.ac.uk

Formatted: Font colour: Text 1

Formatted: Font colour: Text 1

Christian Frost

School of Architecture and Design, Birmingham City University, UK

christian.frost@bcu.ac.uk

Jieling Xiao

School of Architecture and Design, Birmingham City University, UK

jieling.xiao@bcu.ac.uk

Formatted: Font colour: Text

Formatted: Font colour: Text 1

Key words: Abstract:

\section{Figure caption:}

Exhibition, "Architecture, Festival and the City," at Parkside Gallery, Birmingham School of Architecture and Design, Birmingham City University, UK. Photograph by María José Martínez Sánchez, 2017.

\section{Architecture, Festival and the City: Introduction}

The theme of this issue of Architecture and Culture is "Architecture, Festival and the City." Our aim has been to posit and to explore the relationship between festivals and their settings, in order to ask what constitutes festival in the contemporary city - what allows a traditional festival to endure, and how can a new festival become meaningful? The papers originate from the 14th conference of the Architectural Humanities Research Association (AHRA), held at Birmingham City University in November 2017, which itself grew out of our own research interests - Christian Frost's in the persistence of the Florentine festival of San Giovanni and its significance as a representation of civic order, María José Martínez Sánchez's in the 
articulation of public and civic spaces through performance, and Jieling Xiao's in the sensory experience of public space. Although all of the contributions address the main themes of the journal they do so from a variety of different standpoints - from history and anthropology (citing Joseph Rykwert and Victor Turner) through literary theory (building on work by Mikhail Bakhtin) and phenomenological hermeneutics (Hans Georg Gadamer) to performance and art practice (referencing Richard Schechner) to name but a few key sources.

Collectively, the papers explore the genesis of festivals and their continuity - often brought about, paradoxically, through changes to traditions, changes resulting from historical events. The importance of the specific temporality and the liminal status of festivals is made clear through discussions particularly of contemporary festive events, in which boundaries between "public" and "private" are frequently called into question. These themes, of festival and tradition, festival and time, festival and place, guided our editorial and curatorial decisions as we considered how to instigate the "Architecture, Festival and the City" conference and its exhibition as a festive event in its own right, and to understand its resultant publications (a book of the same title, and this journal issue) as versions of its continuity. ${ }_{1 \mathrm{~A}}^{1}$

Formatted: Font colour: Text 1

Formatted: Font colour: Text 1

\section{Festival, Community and Tradition}

Historically, the urban festival served as an occasion for affirming shared convictions and identities in the life of the city. Whether religious or civic in nature, these events provided tangible expressions of social, cultural, political and religious cohesion, often reaffirming a particular shared ethos within very diverse urban landscapes. In the life of any city some festivals inevitably become obsolete, some start afresh, while others transform into new expressions of communality.

Architecture, both temporary and permanent, has long served as a key aspect of festive space, exhibiting continuity in the flux of these representations, whether through the parading of elaborate ceremonial floats in such cities as Venice, Florence and Rome (from the 13th through to the 17th century) or through contemporary manifestations such as Notting Hill Carnival in London, Rio Carnival in Brazil, or the "Day of the Dead" throughout the Americas. Although many of these events are different each year, they are also the same, providing particular examples of an architectural continuity through change and have inspired recent events such as Suz o 
Suz by La Fura dels Baus, Macumba Antropofagica by Teatro Oficina both discussed by María José Martínez Sánchez'and Aleksander Dundjerovic as well as other festival forms, such as annual music or poetry festivals, or political rallies such as the red Festival discussed by Igor Marjanovic and Katerina Ruedi Ray, which, although they may be very precisely stage-managed, are festival-like in their regular but temporary transformation of the urban environment. These developments raise important questions about the definition and status of festival, also carnival and ritual, in the contemporary world, and the extent to which traditional practices can serve as meaningful references.

A key issue here is that of tradition itself. Any festival derived from a historical precedent is never merely a historicist reproduction of that precedent as Huichao Feng and Jieling Xiao argue is the case in the funeral traditions of the Mosuo people; it participates in an understanding of history, drawing on what philosopher Hans-Georg Gadamer calls "effective historical consciousness." ${ }_{\Delta A}^{2}$ Gadamer uses this phrase in order to emphasize the way in which our context, our situation, in the form of traditions, always has influence on our understanding - our consciousness cannot help but be affected by these "horizons." Awareness of this aspect of consciousness is necessary if the horizons open to festive experience are to be truly evaluated:

A person who has no horizon is a man who does not see far enough and hence overvalues what is nearest to him. Contrariwise, to have a horizon means not to be limited to what is nearest, but to be able to see beyond it. A person who has a horizon knows the relative significance of everything within his horizon, as near or far, great or small. ${ }_{\mathrm{A} A}^{3}$

Gadamer argues that a "horizon" has a temporal as well as a spatial component. Although it is potentially open to each individual equally in relation to their "Being," it is inevitably, and necessarily, limited by cultural prejudices that contribute to the framing of any particular activity in any one society. ${ }_{4 \Delta}^{4}$ So although the horizon of human understanding is ultimately qualified only by the limits of being, it is the prejudices of tradition and culture, of "effective historical consciousness," that create the most tangible limits to our attempts at understanding. Festival, then, affirms traditions - it cannot do otherwise - but it also tests and questions them. Many of the papers selected for the conference, and for this journal, describe the ways in which
Formatted: Font colour: Text 1

Formatted: Font colour: Text 1

Formatted: Font colour: Text

Formatted: Font colour: Text 1
Formatted: Font colour: Text 1

Formatted: Font colour: Text 1 
festival is actively involved in developing a fusion of past and present horizons, rather than celebrating a victory of one over the other. Federica Fava's paper, on the festival of Estate Romana, instituted in Rome in the summers of the 1970s, discusses directly the re-interpretation of the past that was essential to its re-evaluation of present possibilities. The work of the Spanish theater company La Fura Dels Baus mentioned above uses its audience's familiarity with traditional religious festivals, taking place in the city, in the round, to reconfigure expectations of what it means to go to the theater - to ask whether a member of the audience is simply a viewer watching a spectacle, or a member of a community, participating in a festival, and called upon to witness particular acts.

\section{Festival and Time}

Perhaps the most significant aspect of a festival that distinguishes it from mere spectacle is that of its particular temporality as an event. Linked to the ideas of tradition and history is the specific experience of the festival. Rather than the familiar "time-experience of the present: memory and expectation," that of the festival is "celebration, a present time sui generis." The importance of the festival is in the present time of the act of celebration that constitutes it; its regular repetition continually reasserts that present time. ${ }^{5}$.

The praxis of festival events has been investigated by many, including Victor Turner, who argued that the time experience of festivals is framed by three levels of engagement: separation, transition and incorporation. Everyone present at the event is "separated" from the rest of the population into a community "out of time." ${ }^{6}$ Next are those who engage more fully, who experience transition, "a sort of limbo which has few $[\ldots]$ of the attributes of either the preceding or subsequent profane social statuses or cultural states." Finally there are the participants or performers in the festival who, by assuming another identity related to the event, are incorporated in it. Through his description, Turner was trying to articulate a deeper, universal experience associated with festival, understood as ritual and performance, that led to a different type of community which he labeled communitas. For him, this communitas was formed and revealed through the event itself, and was related to a state of being he called "liminality" that emerged in a "time out of time," characterized as "festival time." ${ }_{A \wedge}^{8}$ In
Deleted: , on show in the exhibition and discussed in the paper included here by María José Martínez Sánchez and Aleksander Dundjerovic,...

\section{Formatted: Font colour: Text 1}

Formatted: Font colour: Text 1

Formatted: Font colour: Text 1

Formatted: Font colour: Text 1

Formatted: Font colour: Text 1 
this way, in Turner's account, the variety of experiences people encounter during a ritual are accounted for at an ontological level.

Although such a description of the festive experience suggests that festival's "time out of time" might be seen as separate from secular, everyday time, it is in fact enfolded within it. The paper here by Feng and Xiao, on the funeral rites of the Mosuo people in southwest China, by positing funeral as festival, makes this very clear - the funeral events it describes are both part of, and distinct from, the everyday practices of the Mosuo. Feng and Xiao show that this relationship between the everyday and the heightened experience of festive activity in time is similarly valid when assessing spatial aspects of festival - all of the experiences described by Turner, however other-worldly they may seem, happen in a real place, with real boundaries and thresholds and everyday functions and meanings.

\section{Festival and Place}

The festive events described in the paper by Marjanovic and Ruedi Ray, "Red Festivals: Embodying the Carnivalesque in Architectural Pedagogy," were brief episodes of transformation brought about by schools of architecture temporarily established in villages in Eastern and Central Europe during the 1970s and 80s. The architects, whether students or tutors (the roles became blurred) drew on medieval folk traditions to bring students and villagers, learning and citizenship together. But while their examples are rural, their reference - that which they are liminal to, and therefore, however momentarily, they transform - is the city. Although many traditional feasts and rites originally emerged from agrarian rites and rituals, the festival is fundamentally linked to the idea of the city, the polis.

Fustel de Coulanges, in his work on religion and the ancient city, suggests that the Greek polis was formed of three layers of association: the family, the tribe and the city itself. ${ }^{9}$ Such cities (however gradually they may actually have grown) were understood to have come into existence through a ritual act of foundation - or dromenon - that established the sacred boundary separating city (order) from wilderness (disorder). Joseph Rykwert argues that:

...the origin of [the foundation] rite cannot ever be found in speculation, whether 'rational' or 'mythical.' Its origin will always be in a dromenon, in an
Deleted: Huichao

Deleted: Jieling
Deleted: Igor

Deleted: Katerina
Formatted: Font colour: Text 1

Formatted: Font colour: Text 1 
action, and such origins are always lost. The search for the 'pure' and original form of the rite would be entirely fruitless. ${ }^{10}$

Rykwert's point is that the ritual act that founds the city is valid only in its subsequent celebration. The origins of a city founded by rite are lost unless they are continually re-enacted, and the re-enactment alters in line with the times. Each enactment harbors crucial aspects of the origin, form and temporal rhythm of the city that recall continuities, but they can also change in meaning - as is seen, for instance, in the development of the contrast of rus and urb in antiquity to become a contrast of nature and culture in the Middle Ages ${ }_{2}^{11}$ both versions helping to establish the meaning of the difference between natura naturata and natura naturans in the Renaissance. ${ }^{12}$ Coulange's stratification from family, through tribe to city, like Turner's modes of engagement, suggest a critical relationship between 'public' and 'private' modes of engagement which changes during festivals. Throughout such evolutions and changes, a "time out of time" can be choreographed within the same city, on the same date each year, in a celebration which is both a historic re-enactment and a contemporary statement of belonging. The Estate Romana discussed by Fava might be seen as a contemporary extension and adaptation of the Roman feast of parilia celebrated on $21^{\text {st }}$ April, a festival that commemorates and, even to this day, re-enacts aspects of the original idea of Rome.

However, many historical descriptions of festivals have little to say about either the various aspects of temporality mentioned above or the place within which the events occur. Both conditions, of place and of time, are just accepted as given - as the background to the dominant narrative of the celebration itself. Anne Hultzsch's paper, published here, on the depiction of festivals and processions in the Illustrated London News of the 1840s, examines closely how the muting of the architectural setting allows the reader to focus on the festival "in flux." Yet this does not mean that architecture and the city can be considered neutral in relation to civic events: Eric Parry, a keynote speaker at the conference and interviewed here by Christian Frost, hints that this "background" status of most urban architecture is exactly what is important about it - the role of such architecture is not to speak out, but, in its awareness of the depth of traditions it embodies, quietly to engender ongoing communication, both with the past and in the present.
Formatted: Font colour: Text 1

Formatted: Font colour: Text 1

Formatted: Font colour: Text 1

Formatted: Font colour: Text 1

Formatted: Font colour: Text 1

Formatted: Font colour: Text 1 
If historical accounts of festivals, by taking their settings for granted, seem often to suppress them, some contemporary accounts of events, particularly of political rallies or religious processions, appear to argue for too much influence - as if the Maifeld in Berlin created Nazis, or the Casa del Fascio fascists. ${ }^{13}$ In these examples, architecture can become tainted with abuses of power, or acts of generosity or heroism, or other issues deemed - again by those in positions of power - of significance to civic history. In reality, such spaces can always be reclaimed and festival, such the one described in Mouttalos in Cyprus by Maria Hadjisoteriou, Angela Kyriacou Petrou and Sevina Floridou which re-engages a displaced community, can be used in this process. Consequently, as Parry makes clear, the status of architecture lies somewhere in between these two extremes - it is neither totally neutral nor totally defining. Fava shows us that the specific sites for the celebrations of the Estate Romana were carefully chosen, not because they were all-defining, but in order to allow the festival to transform perceptions of them. The paper by Yun Gao, Yan Li and Nicholas Temple, "The Commercial Street as 'Frozen' Festival," treats delicately the importance in contemporary Chinese cities of retaining a "traditional street," whether newly built or part preserved, as a site for the continuing celebration of familiar festivals; they suggest that these streets tread a fine line between foregrounding themselves and remaining in the background, between maintaining continuity and presenting festival as commercial spectacle.

\section{Festival and Performance}

Saul Steinberg's 1942 drawing of Strada Palas, the Budapest street he lived in as a child, analysed here by Andreea Mihalache, shows the street itself as festival, as a parade. No longer a static setting, it has become a performance, in which animated architectural elements, people and other creatures act out their allegorical roles. In her discussion of Iannis Xenakis" "polytope" installation at the Montreal World's Fair of 1967, Ruth Bernatek points of light and orchestrated sound, activated by and enveloping visitors to the French pavilion, that become part of the show. In both cases audience and performer have become one and the same.

Turner's account of the festival, with its distinctions between different levels of engagement - performers, audience, and hosting community - points directly to its close links with performance. But, different from spectacle, it is not only those who 
perform the key roles in the festival who are essential to its action; those who witness it are equally important. Both witnesses and the leading players are drawn into the liminal, ephemeral "communitas" that is created. In this way the festival is performative - it has an effect on all those involved.

As we selected and assembled material for the conference, and for the multimedia exhibition that accompanied it, it became clear that many of the recent or contemporary versions of festival that we were learning about drew explicitly on its links with performance and its claims to performativity. We asked dancer Rosie Kay, interviewed here by Martinez Sanchez, to be one of our keynote speakers; both in her talk and in the exhibition, she showed audiovisual recordings of some of her sitespecific performances in public squares, hospitals, train stations, even on trains themselves; her work is extraordinary in its ability to draw people out of their everyday lives and spontaneously to join in the dance. Not only do performance and place inflect each other, but also, for a moment, a new community is made.

As well as the theater work of La Fura Dels Baus, the exhibition included material from Brazilian theater company Teatro Oficina's performance of Macumba Antropofaga (both companies provide case studies for the paper by Dundjerovic and Martinez Sanchez). The performance took place in Sao Paulo in July 2017. It began in the theatre designed by Lina bo Bardi, a building that reflects in architectural form the idea of the street, before it ventured into the city beyond. The performance integrated within it the urban reality of the favelas, creating a festival that brought together audience, performers and people who lived in the area, blurring the boundaries between these different groups and creating, however fleetingly, a sense of community between them - a heady sense of trust that, in this case, allowed public nudity to seem fully acceptable.

This transgression from accepted norms is, for Mikhail Bakhtin, an essential feature of carnival. It was in mounting the exhibition, with its images from this performance, and also from popular festivals such as the Rio Carnival, Spanish Easter processions and bullfighting, that we became aware that our own activities might be perceived as transgressive. Although all the events shown took place in public spaces, they did so by creating moments of "time out of time." In the exhibition, the nudity in the work of
Commented [PD1]: Is this true?

Commented [CF2R1]: She did use this info in the exhibition and her keynote. Is that what you mean?

Formatted: Font colour: Text 1

Formatted: Font colour: Text 1 
both Teatro Oficina and La Fura Dels Baus, and the staged violence of the bullfight, was deemed inappropriate by the university authorities, particularly for a potential audience of children. We had been thinking as academics, using the work to raise theoretical questions about the performative nature of festival, not yet as festival organizers ourselves. ${ }^{14}$

\section{$<$ insert figure 1 here $>$}

\section{Festival as Conference}

One of the events documented in the exhibition was the celebration, organized by the $\mathrm{F}=$ Research Group based at Leeds Beckett University, of International Women's Day on March $8^{\text {th }} 2017$ - a walk through the city center followed by the ritualistic burning of a large symbolic object amidst several different performances, an exhibition and a conference in the City of Leeds Public Library.

Our conference was less militant, less single-minded. It aimed to raise questions rather than necessarily to answer them. But it was certainly festive. We imagined it as a festival of creativity, a space and a time for developing and testing theoretical ideas and concepts, for meeting together and suggesting the possibility of future collaboration. The conference dinner, always key to conviviality, was hosted not at the university, but in Birmingham's city center, so that all those who came paraded through the city streets. The keynotes talks were delivered in a multidisciplinary performance space to encourage engagement and participation. The program of events was announced in a specially-made newspaper, familiar to all contemporary festivalgoers, to imply that participants could drop in and out of discussions and debates while still being engaged in the whole.

The conference, with its exhibition, was made up of many different narratives of festival from different parts of the world and from different traditions. Together, they explored what we mean by the word "festival," identifying different kinds and levels of involvement or participation, and exploring different roles for architecture, whether ephemeral or permanent. New roles for festivals and new ways of creating them were put forward, some of them recorded here in the short papers documenting events in Groningen (Annalise Varghese, on the role of the pavilion), Birmingham (Jenny
Commented [PD3]: Is this true? If so, you could put a footnote at the end of this sentence to give the exhibition venue, and highlight Maria's role.

Commented [CF4R3]: Yes it was true

Formatted: Font colour: Text 1

Formatted: Font colour: Text 1

Formatted: Font colour: Text 1

Formatted: Font colour: Text 1 
Peevers and Alessandro Columbano on different practices of making in the city) and Cyprus (Hadjisoteriou, Kyriacou Petrou and Floridou on an event to enfranchise a displaced community). New festivals were proposed, festivals that could have an impact on future thinkers about the city as polis and as place, as well as on the collective memory of those present.

The event is now over, but it can, of course, be re-enacted in a different guise. In her paper "On Playgrounds and the Archive: Joan Littlewood's Stratford Fair, 19671975," Ana Bonet Miro argues that the Fun Palace of Littlewood and Cedric Price lives on, in the space that establishes itself between the various different archives in which its activities are logged. This journal, and the Architecture, Festival and the City book are among the sites where the conference's events find their record, and from where they can be taken up anew.

\section{References:}

Arndt, Karl. 1995. 'Paul Ludwig Troost als Leitfigur der Nationalsozialistischen Repräsentationsarchitektur'. In Bürokratie und Kult: Das Parteizentrum der NSDAP am Königsplatz in München. Geschichte und Rezeption, edited by Iris Lauterbach, 147-56. München: Deutscher Kunstverlag.

Białostocki, Jan. 1963. The Renaissance Concept of Nature and Antiquity. Princeton, NJ: Princeton University Press.

Bakhtin, Mikhail. 1984. Rabelais and His World, trans. Helene Iswolsky.

Bloomington, IN: Indiana University Press.

Browne, Jemma, Christian Frost and Raymond Lucas, editors. 2018. Architecture,

Festival and the City. London: Routledge.

Doordan, Dennis P. 1988. Building Modern Italy: Italian Architecture, 1914-1936. New York, NY: Princeton Arehitectural Press-1.

Dundjeroviç, Aleksandar. 2013. "Freezing of Collective memory: The Trial of Harold

Pinter," Performance Research Journal, 18, no.6: 137-145.

Commented [CF5]: Shouldn't this be in?

Formatted: Font colour: Text 1

Formatted: Font colour: Text 1

Gadamer, Hans Georg. 1976. Truth and Method, trans. William Glen-Doepel. New York: Sheed and Ward.

Le Goff, Jacques. 1992. The Medieval Imagination. Chicago, IL: University of Chicago Press. 
Schechner, Richard. 2003. Performance Theory. London: Routledge.

Rykwert, Joseph. 2010. The Idea of a Town: The Anthropology of Urban Form in Rome, Italy and the Ancient World. London: Faber and Faber.

Turner, Victor Witter. 1982. From Ritual to Theatre: The Human Seriousness of Play. New York: Performing Arts Journal Publications.

Vesely, Dalibor. 2004. Architecture in the Age of Divided Representation. Cambridge, MA: MIT Press.
Commented [PD6]: Should this still be getting footnoted?

Commented [CF7R6]: I have added it to the introduction

Formatted: Font colour: Text 1

Formatted: Font colour: Text 1

1 Jemma Browne, Christian Frost and Raymond Lucas, eds., Architecture, Festival and the City (London: Routledge, 2018).

${ }^{2}$ Hans Georg Gadamer, Truth and Method, trans. William Glen-Doepel (New York:

Sheed and Ward, 1979), 267.

${ }^{3}$ Ibid., 269.

${ }^{4}$ Ibid., 238.

${ }^{5}$ Ibid., 110

${ }^{6}$ Victor Witter Turner, From Ritual to Theatre: The Human Seriousness of Play (New York: Performing Arts Journal Publications, 1982), 24. "Out of time" here means outside our normal time, which measures everyday processes and routines.

${ }^{7}$ Ibid.

${ }^{8}$ See Chapter 3 in Victor Turner, The Ritual Process: Structure and Anti-Structure (Oxford: Routledge, 2017).

${ }^{9}$ Numa Denis Fustel de Coulanges, The Ancient City: a Study on the Religion, Laws, and Institutions of Greece and Rome (New York: Doubleday, 1955 [1877]).

${ }^{10}$ Joseph Rykwert, The Idea of a Town: The Anthropology of Urban Form in Rome, Italy and the Ancient World (London: Faber and Faber, 2010), 88.

${ }^{11}$ Nature was associated with the ocean and forest - the western equivalents of the eastern desert - and culture with the city, castle, village etc. See Jacques Le Goff, The Medieval Imagination (Chicago: University of Chicago Press, 1992), 58.

12 Jan Białostocki, The Renaissance Concept of Nature and Antiquity (Princeton, NJ: Princeton University Press, 1963).

${ }^{13}$ For example on Nazi architecture see Karl Arndt, 'Paul Ludwig Troost als Leitfigur der Nationalsozialistischen Repräsentationsarchitektur', in Bürokratie Und Kult: Das Parteizentrum Der NSDAP Am Königsplatz in München. Geschichte Und Rezeption, ed. Iris Lauterbach (München: Deutscher Kunstverlag, 1995), 147-56. 147. And for Italy see Dennis P. Doordan, Building Modern Italy: Italian Architecture, 1914-1936 (New York, NY: Princeton Architectural Press, 1988), 129ff.

${ }_{14}$ Alongside the Conference was a multimedia exhibition curated by Maria Jose Martinez Sanchez, that expressed the different characteristics of festivals, and public and civic events around the world. The presentation of festivals illustrating the conference themes through different media was an invaluable contribution to the research that is evident in this journal. The exhibition included work by conference 
contributors and keynotes speakers in addition to other work curated specially for the event. 